\title{
Microfinance Survival: The Impact of Credit Management on the Sustainability of Micro Finance Institutions in Cameroon
}

\author{
Ruth Endam Mbah ${ }^{1,2,3 *}$, Divine Forcha Wasum ${ }^{4}$ \\ ${ }^{1}$ International Center for IT and Development (ICITD), Southern University and A\&M, LA, USA. \\ ${ }^{2}$ Department of Public Policy, Southern University and A\&M, LA, USA. \\ ${ }^{3}$ Nelson Mandela Institute for Research (NMIR) \\ ${ }^{4}$ CIFE, Centre International de Formation Européenne, \\ * E-mail of the corresponding author: endamruth@yahoo.com
}

\begin{abstract}
Just as there is rapid growth of Microfinance institutions in Cameroon, there is an alarming rate of bankruptcy, and consequently closure by these institutions. The prevalence of numerous closures of long time well-known microfinance institutions in Cameroon serves as the impetus for this research in an effort to seek and find the main cause of these closures. The credit management process was seen as the major cause of most of these sudden closures due to poor loan portfolio management. In 2014, Cameroon had 500 microfinance institutions and by 2015 only 418 microfinance institutions were listed (CRTV 2015). Renowned microfinance institutions left a huge clientele financially incapacitated due to their unexpected bankruptcy and closure. This research selected one highly rated functioning microfinance institution to find out the lapses in the credit management process. Data was collected using questionnaires, direct observation and secondary data. Data analysis is descriptive. Results show that there were a good number of lapses like: high provision, poor recovery procedure, credit officers without an educational background in the field, manual execution of some loans, slow credit management processes, bad faith of customers and poor follow up of loans given out.
\end{abstract}

Key Words: Credit Management, Microfinance Institution (MFI), Recovery Procedure, Lender, Borrower, Bad debt, Doubtful debt, Microcredit

DOI: $10.7176 / \mathrm{HRL} / 50-05$

Publication date: December $31^{\text {st }} 2019$

\section{Introduction}

A microfinance institution is one that offers financial services to low income population who do not have the financial capacity to acquire the services from big financial institutions such as banks. Today it is a highly utilized means of financial assistance and survival for most low income earners especially in lest developed nations where the economy does not permit citizen the luxury of commercial banking institutions. Petty traders, house wives and even students can save, borrow and even transfer funds affordable interest rates through such microfinance institutions. The notion of microfinance has its roots from the $19^{\text {th }}$ century when the theorist Lysander Spooner wrote over on the merits from small credits to entrepreneurs and farmers as a means of alleviating poverty. The concept gained great impact with the Marshall plan after the Second World War. Pioneers of this concept in the 1970s include Grameen Bank of Bangladesh, Mohammad Yunus (receiver of the Nobel Prize 2006), Akhtar Hammeed Khan, Shorebank in Chicago, Friedrich Wilhelm Raiffeise's village bank movement in Germany, caisse populaire movement by Alphone and Dorimene Desjardins in Quebec. In February 1997, the first Microcredit Summit was launched by RESULTS educational Fund (REF) which was a none year campaign to access 100 million poor homes of the world especially the women of such homes with microfinance facilities by the end of 2005. This took place in Washington DC with over 2,900 delegates from 137 countries. The first phase was successful as microloans grew from reaching 7.6 million poorest homes of the world in 1997 to more than 100 million in 2007. Since then, this summit has had as mission to alleviate poverty through follow-up of the microfinance sector (Microcredit Summit Campaign, 2017). Many see microfinance as an answer to low income earners, a means to promote economic development, employment and growth as these institutions help support small businesses through microcredit. Microcredit off course is just a subset of microfinance though both terms are always confused. Microcredit deals with the provision of loan facilities to the low income earners. It is believed that these microcredits are given out at affordable rates. The reality is that these loans are actually given at high interest rate when calculated cumulatively over the life span of the loan. This is because the risk involved in such loans is higher since these are low income earners and the rate of default is high. Most microfinance institutions equally survive principally on the interest they get from such loans. The survival of these institutions is therefore very vital for economic growth and poverty alleviation. In Cameroon, the Finance Minister- Alamine Ousmane 
Mey published a list of microfinance institutions (MFIs) authorized to operate in Cameroon. There were a total of 418 for 2015 compared to over 500 in 2014 (CRTV, 2015). In a year, almost one hundred were removed from the official accredited list due to various deficiencies.

This study seeks to explore the impact of credit management on the sustainability of microfinance institutions in Cameroon, through a case study; Community Credit Company Plc. The research will:

$>$ Evaluate to what extent the MFI follow its credit management policies and procedures;

$>$ Assess the effectiveness of these credit management policies/ procedures and their impact on the borrower and sustainability of the institution;

$>$ Evaluate the perception of the borrowers towards the credit management policies/procedure and how this is linked to the growing provision on bad debts;

$>$ Examine the credit risk mitigation measures put in place by MFI; and

$>$ Evaluate the effectiveness of recovery policies put in place MFI

\section{Literature Review}

\subsection{History of Micro-Loans}

The development of micro- loans or microcredit to alleviate poverty in the poorest nations of the world can be traced back to the 1970s in Bangladesh. The development of microcredit according to most writers in this field was initiated in Bangladesh when the pillar of the Grameen Bank, Professor Muhammad Yunus receipient of the 2006 Nobel Peace Prize encouraged the rise of financial institutions that would readily make available financial resources for the poor. According to Professor Yunus, a collection of these persons could sum up to make up what he called the 'biggest development wonder', (Grameen Foundattion 2013). According to him, everyone in society should be given an opportunity to loan money no matter their economic condition. He saw this as a human right. This vision led to the creation of the creation of the Grameen Bank which is a microcredit institutions which is committed to encourage self-employment by giving out small working capital to the poor especially women. Over 6.5 million dollars have been loaned out to the poorest of the poor over the last two decades and a majority being to women. This has pushed a rapid growth of microcredit movement worldwide reaching out to poor especially the poor women. His life story "Banker to the Poor: Microlending and the Battle Against World Poverty," has been interpreted into several languages of the world like: French, Italian, Spanish, English, Japanese, Portuguese, Dutch, Gujarati, Chinese, German, Turkish and Arabic, (Grameen Foundattion 2013).

Due to the need for financial institutions that will serve the poor, in 1973 ShoreBank, a community development bank was founded in Chicago. Its mission was to meet the financial needs of the low income neighborhoods especially the African-Americans. Its involvement in reshaping and stabilizing the poor neighborhoods of Chicago soon made it global and it set a standard for the development of the financial sector. Executives from this bank were involved in the development of the microfinance industry internationally. Its accomplishments in Arkansas motivated Bill Clinton, then governor to put forward the Community Development Financial Institutions Act, which he signed in 1994, (Douthwaite, Richard 2007). Due to its rising influence, in the 1980s, ShoreBank worked alongside Muhammad Yunus to assist him incorporate Grameen Bank in Bangladesh under a grand from the Ford Foundation (Glenn, Brandon, 2007).

\subsection{Credit Risk as an Impediment to the Survival of Microfinance Institutions}

Like any other financial institution, microfinance institutions encounter various forms of risks but their intensity is due to their small sizes and their volume of operations. Of all the risks a financial institution could face, credit risk is one of the most sever. Credit risk is the possibility that a borrower (one who binds himself to make payments) will not meet his/her obligations in line with the agreed terms, resulting in financial loss (Ibrahim, 2010). As much as these institutions exist to receive deposits, they equally give out loans and thus, cannot avoid credit risk (Kolapo et al, 2012). Thus, the sustainability and survival of these institutions depends on how well they can mitigate this credit risk. Most of the world's poorest countries and especially Sub-Sahara Africa depend on the survival of microfinance institutions for economic development. This part of the world in made up of low income earners who depend of microloans for their working capital. Due to the economic situation of such nations, most of these petty traders close down from high competition from the international competitors. This means their loans repayment would not be possible. This loan default equally implies that the lenders (microfinance institutions) will not only loose the interest on loans but a huge portion of the unpaid principal amount. This means depositors will not have their funds available when they need them. What next, closure of the institution especially if it cannot meet its running expenses or demands from depositors. For instance, in Cameroon, the Finance Minister- Alamine Ousmane Mey published a list of microfinance institutions (MFIs) authorized to operate in Cameroon and there were a total of 418 for 2015 compared to over 500 in 2014 (CRTV, 2015). 


\subsection{Causes of Credit Risk in MFI}

Haron, Justo, Nebat \& Mary (2012) evaluated the effectiveness of credit management system on loan performance: empirical evidence from microfinance sector in Kenya and came out with the following results from a target population of 70 credit officers of the 14 microfinance institutions registered and operating in Meru town: the nonperformance of loan was contributed to top management not being involved in the credit policy formulation. Just like Fernando (2006) the interest rate had an impact on the loan performance in microfinance institutions. Amazingly this research showed that the condition of the loan did not affect the loan performance of microfinance. This is in contracting because there exist various types of loans having different requirements and not all customers will praise the conditions surrounding these loans. Also if the interest rate has an inverse relationship with the loan performance as proven by the results of this study, there should definitely be a relationship between the condition of the loan and the loan performance given interest rate is one of those conditions.

According to Alex Addae (2014) the causes of loan default in microfinances institutions in Ghana are numerous. From his results, clients acknowledged the fact that they did not receive proper training about the loan process before indulging into it. Just like most other findings, high interest rate and unfavorable repayment conditions pushed loan clients to default. Long waiting time for the loan to be approved and disbursed was seen as a factor for default repayment. Other factors like, illiteracy, unwillingness to pay, poor management of the loan granted and poor recovery measures contribute to loan default among microfinances in Ghana.

As for Priya Chetty (2017), the ill effect of over giving out money and a bad recovery practice by microfinance institutions is the cause of the recent Andhra Pradesh microfinance crisis. The quest to raise sales target pushed most of these institutions to give out huge loans at excessive rates without considering the repayment capacity of the clients. The clients were unable to repay back these loans at their maturity dates leading to detrimental recovery capacities.

\subsection{Credit Risk Management for Sustainability of MFI}

Credit risk is at the center of most of the crisis microfinance institutions find themselves in. Credit risk management thus involves various means put in place to mitigate this risk. From the recent Andhra Pradesh microfinance crisis, Priya Chetty (2017) said India has been taught the significant importance of the bank's involvement in checking the credit worthiness of every loan applicant. Also loans should be given out at affordable interest rate in order to encourage repayment. Recovery procedures should be in a manner that will preserve the lives of the customers. Above all, she suggested that a better credit risk management procedure should be put in place that will frequent check the excesses of the loan process and reduce loan default. Alex Addae (2014) article equally agrees on the fact that loans should be given out at affordable interest rates and a thorough check of the customer should be done. He added that timely disbursement of funds is necessary as well as training before and after disbursement. Both agree on the point that recovery should be efficient as Alex went further to suggest that a quick recovery action should be put forth immediately after the first period of default.

Lawrence (1997) put forth what is commonly known as the Five C's of Credit: capacity, capital, collateral, conditions and character. According to Lawrence every lender should be able to verify the Capacity of the borrower to repay the load. Every lender will want to know how long it will take to recover back his money and the capability of the borrower to pay in due time. According to Lawrence a thorough review of the borrower's Capital structure is important. It is necessary to know how much of the business' total capital is provided by the borrower himself. It is dangerous to lend money to someone whose business is totally depended on borrowed money. Collateral should be provided in case there is a default. The value of the collateral should equal the amount borrowed. It will be of added advantage if collaterals that are affected by market value be of a greater value than the principal amount borrowed. Condition involves the reason for the loan. It is important to know what the borrower wants to do with the money. It should be a productive investment that will generate money for repayment. Lastly Character as proposed by Lawrence is the ability of the lender to subjectively determine the willingness of the borrower to repay his loan. These five factors according to Lawrence will help reduce loan default if effectively and efficiently used.

According to Chijoriga (1997) and Basel (1999) credit risk is the most costly to financial institutions and its consequences are more significant than another risk a financial institution could face since it directly affects its solvency. This therefor must be managed in order to sustain the financial institution. Saunder \& Linda (2010) confirmed this notion and went ahead to propose ways to manage credit risk. According to them, securization is one way to reduce credit risk. This means that, rather than holding loans in their originality on the balance sheet till maturation, the bank could rather sell the loans and other asset-backed securities shortly after origination for cash. This cash can later be used to originate new loans/assets, thus starting the securization process all over. They also proposed loan syndication as another mechanism to reduce credit risk. This happens when a bank gives out a loan to a customer but rather than holding the whole loan, it sells part of it (syndicates) to an external investor who 
can be a hedge fund, mutual fund, insurance company, another bank or investor. When this process is done, the originating bank holds a percentage of the loan (say 20\%) and its associated liability while the external investor holds the other percentage (say 80\%).

In contrast, Hartungi, Rusdy (2007) in their article 'Understanding the success factors of micro-finance institution in a developing country -Bank Rakyat Indonesia (BRI)' deviate their attention from credit management as a primary source of sustainability of microfinance MFI to other factors. The decision of the MFI to keep adapting its practice with environmental changes was seen as a factor that influences the sustainability of MFI. Also innovation in choosing collaterals was another factor since it made credit appealing to the poor class while serving as a security in case of default. Well-trained and dedicated staffs operating a simple, transparent system, clear incentives to staffs and clients, tight internal supervision and audit capacities and financial procedures and sound financial risk management were seen to contribute to its success as well. According to this study environmental (internal and external) influence plays a major influence on the sustainability of the MFI.

\section{Methodology and Research Design}

Case study is one of the popular research methods in business disciplines (Silverman, 2011). This case study was conducted in Cameroon. The target group of this study was the loan clients of Community Credit Company (CCC) Plc and the employees who are directly involved in the credit process in the various branches all over the regions of Cameroon. The sample size was divided into two groups, namely; 200 Clients (civil servants, registered business enterprises and company workers), 80 employees. Raw data was collected directly from people involved in the credit process like: the customers, credit subscribers, credit analysis through the usage of a designed Questionnaire, Interview and Personal Observation. Intense review of books, articles, academic journals (publications) or electronic sources and credit procedure and policies from Community Credit Company Plc made up the secondary data. Data collected was analyzed using qualitative methods. Descriptive statistics made use of percentages, frequency distribution, bar charts and pie chart.

\section{Data Analysis and Results}

The survival of every Financial Institution lies on how it can effectively and efficiently manage its loan portfolio. It is thus, of critical importance for every financial institution to have an adequate and efficient credit policy manual, credit process and credit recovery procedure, recovery procedure and control its provisions if it must survive in this highly competitive sector having clients who are ready to take advantage of any loop holes. The following are the analysis from the survey, observation and questionnaires issued.

\subsection{Network Provisions as at 31st December 2015}

From the data collected on CCC Plc Network Provisions it can be said that it has a lot of matured loans unpaid to the sum of 2194414801 FCFA as at $31^{\text {st }}$ December 2015. There has been an increase of 330457918 FCFA as compared to the figure in 2014 of 1863956883 FCFA. Reasons for this increase in provisions were: The lack of Recovery Officers in some branches with huge provisions; the slow response from recovery proceedings in court; insufficient recovery efforts, sudden withdrawal of important company workers with credit engagements; the windup of some major companies with huge credit engagements; the fraudulent change of mode of payment by some civil servants; misappropriation of funds by customers due to lack of follow-up by branches which defeat the purpose for the facility and jeopardize repayment; the acceptance of non-viable sureties over certain facilities; poor credit analysis and inadequate evaluation of the risk involved by branches and the existence of some financed contracts which are pending payments.

Manual loans equally played a huge part in increasing the provision on bad and doubtful loans. Manual loans are those loans which were given out to customers (mostly relatives to top officials of the MFI) at the early days of the institutions. These loans have no backup files and no records can be found, thus making the recovery of these loans not only slow but very difficult. There is no information about the sureties or any collateral that was used to safe guard for default payment. This makes the process very tedious and in most case is abandoned by most branches because they cannot be traced.

\subsection{Responses from CCC Plc employees}

A sample of 80 employees with credit management knowledge was used for the analysis. All of the employees answered the questionnaires. From the responses, it was discovered that a majority of them were between the ages of 26-38 and 36-45. This is because maturity comes with age and the adult stage is a stage where people can take 
more reasonable decisions and are physically fit for the job. Credit management needs people who are matured and prompt to take decisions which will not lead the company to closure, thus the need for the adult employees. Also, $75 \%$ of the respondents were women, this is because women are more detail oriented and better visual analyst. It is very important to be able to access a client's physical expressions to judge their sincerity.

More than half of the employees are Degree holders, some with Diplomas and few with Master degrees in any related business course. However, all of the employees have passed the Advance Level at High School level but for $5 \%$ made up of the drivers and the cleaners. The higher the educational status of the employees, the higher their effectiveness in analyzing, interpreting and understanding the implication of not effectively analyzing a loan file. This will reduce the risk of having bad loans and clients on the other hand will have adequate and explicit information.

All employees agreed on the presence of a Credit Manual (100\%). There can never be an effective and coherent policy without a manual which is updated as need be. $75 \%$ affirmed that this manual is up to date while $25 \%$ affirmed the contrary. Though every financial institution ought to follow the National Credit Policy Requirement, $60 \%$ of the employees think the credit policy is in accordance to the National Credit Policy requirement while $40 \%$ think otherwise. Though loan is the main product of the bank as it is the main source of income, its growth is not as expected in almost all branches in the region. This is disclosed by $60 \%$ of the respondents. $70 \%$ think the loan service is as client's preferences while $30 \%$ think it is not. Given that each branch is required to give out loans only up to the sum of five hundred thousand FCFA, 90\% of the employees think the lending and overriding limit is an impediment to branch loan capacity and growth while $10 \%$ think it is enough in order to reduce branch excesses. All the employees believe that the collection technique used by the institution is effective given that they have qualified recovery agents and legal minds necessary for an effective control of the loans disbursed.

On the current credit analysis and procedure used by the institution, $75 \%$ of the employees think it is good, $20 \%$ think it is fair, $5 \%$ says it is very good while none of them think it is neither excellent nor poor. This is a very important aspect of the credit management process which can lead to closure of the bank if not well managed.

From analyses about the authorities empowered with loan approval validation, it can be said that CCC Plc has a good approval policy. Individuals are not authorized to approve any loan despite their power. The Branch loan committee can approve only up to 500 000FCFA which helps control the excessive at that level. The Head Office Credit Department does most of the approval while the BOD comes in for very huge sums. This help in reducing the risk of bad and doubtful debts.

For an effective recovery procedure, an analysis of the reasons for default must be done. In order to maintain a good credit portfolio, this analysis is of utmost importance. $45 \%$ of the employees think defaults are due to lack of intensive follow up. A team is scarcely sent to visit the actual resident of the loan applicant, so $30 \%$ said it's due to inadequate check of applicant's information. $20 \%$ said it is due to lack of proper training of the credit officers who are not familiar with the procedures. $5 \%$ attached it to the environmental conditions while no one said it is due to absence of book keeping.

\subsection{Response from Interview to Loan Applicants}

Most of the loan applicants were male rather female. This is due to the fact that, the men are heads of families and have many responsibilities. Most of the applicants were adults who understand what they are engaging themselves into. All of the applicants could read and fill the forms, meaning there was no illiterate among. The older applicants as well as the primary school leavers were assisted in filling the forms but at least had an idea of what they are engaging into.

Most of the applicant said the process is too long with many requirements and paper work. Particularly they complain about the compulsory surety imposed on them even with the assurance of their monthly salary as a guarantee. Added to this, most of the customers tend to inter surety themselves without knowing each other. Also, customers with lesser salary accepted to surety workers with huge salaries, thus bigger loan amount. This plays back on the institution when the loan applicant runs away and the surety's salary cannot cover the bad loan. The bank officials say it's the surest form of repayment if the applicants run away. The applicants affirmed to have received adequate information about the loam process though they find the charges too high.

Shocking enough, the bank officials rarely visit the loan applicants' premises in order to know where they could be traced in events of default payment. Only applicants with huge amounts have their premises and guarantee visited and evaluated. Despite this shortcoming, many applicants say they will repay their loan because they intend to take another loan in the future. A loan customer can only take another loan when his/her current loan is finish or half of the installment has been paid off. If the loan has been paid half way, the formal loan will be anticipated and an anticipation of $3 \%$ is cut on the amount. The applicant is then given the balance. 


\section{Conclusion and Recommendations}

\subsection{Conclusion}

Every Micro-finance Institution in Cameroon is sustained mostly by the proceeds gotten from loans give out to customers. The management of this process is therefore of utmost important because it can negatively affect the performance of these institutions if not well managed. The survival of these institutions would depend of how effective they can recover the loans they have given out while making gains from the interest paid. This money given out belongs to customers who at one point in time will need their savings back and the bank will have to make it available on time. Thus, they need to manage credit effectively so that they do not go bad and obstruct the payment of the savings of those who had saved.

\subsection{Recommendations}

Based on the research findings the following recommendations are brought forth

$>$ Microfinance institutions should employ staff with credit management educational background at the credit unit and constantly train them

$>$ Credit clients should equally be educated on the various types of loans and their requirements.

$>$ Interest rates be reasonable in order to ensure payments and not discourage the clients.

$>$ There should be proper recording of the loan procedure in order to avoid the negative effect of manual loan. Records should be kept physically and electronically for archival purposes.

$>$ There should be proper follow up of customers from the day a loan request is filed it. Huge sums of money should not be given out without knowing the permanent resident of the customer.

$>$ Collateral values should be above the principal amount of the loan to cover up for devaluation.

$>$ An accurate and diligent recovery team should be put in place, so that each loan file can be followed up after the first default payment. Payrolls should be monitored in order to get a quick report of any customer whose salary did not appear and is on loan for follow up.

$>$ Loans should be insured. Though it increases the cost of loan procurement, it is advantageous to the institution. This insurance should not only cover loans of deceased customers but incapacitated consumers due to job related accidents or ill health.

$>$ Uniform Act Organizing Simplified Recovery Procedures and Measures of Execution from OHADA (The harmonization of business law in Africa) should be followed by recovery agents and the institutions lawyers. This law provides a simplified recovery procedure.

$>$ The idea of a surety for each loan request is good but customers with lower income should not be allowed to surety those with higher income. In an event of default payment, the smaller salary earner will not be able to survive if he has to repay a loan he earlier surety.

\section{Reference}

Anoukaha F. (2009). La Commercialité Dans le Droit OHADA. University of Dschang.

Basel. (1999). Principles for the Management of Credt Risk. Basel Committee on Banking Supervision, Basel. Casu, B., Girardone, C. \& Molyneux, P. (2006). Introduction to Banking, Pearson Education Ltd. Prentice Hall. Chijoriga, M. M. (1997). Application of Credit Scoring and Financial Distress Prediction Models to Commercial Banks Lending: The Case of Tanzania. Ph.D Dissertation, Wirts Chaftsnnversitat Wien (WU), Vienna

Cooper. R. Donald \& Emory. C. William (1995). Business Research methods, $5^{\text {th }}$ Edition

Douthwaite, Richard. How a Bank Can Transform a Neighbourhood., "Short Circuit". Retrieved on January 8, 2007

\section{Edition}

Feigenberg, Benjamin; Erica M. Field; Rohan Pande. "Building Social Capital Through MicroFinance". NBER Working Paper No. 16018. Retrieved 10 March 2011

Gaitho.M. (2010). Credit risk management practices by Saccos in Nairobi.

Glenn, Brandon. "ShoreBank leaders had hand in Nobel Prize", Crain's Chicago Business, 2006-10-16. Retrieved on January 8, 2007

Harlow Colquitt, J. (2009). Credit Risk Management, 4th Edition. McGraw Hill, New Jersey.

Horcher, K. A., (2000), Essentials of Financial Risk Management, Hoboken: John 
Laurent Lheriau (2009). Précis de règlementation de la microfinance, Agence Française de Développement. COBAC (2008) Enquête Statistique sur les EMF de Petite Taille dans la CEMAC (Statistiques arrêtées au 31 décembre 2008)

Leonard Ajonako T. The Microfinance Market of Cameroon,2012

Longman Business Dictionary. (2003)

Macmillan English Dictionary, (2002) for advanced learners. Compiled and edited by the Reference and Electronic media Division of Bloomsbury Publishing Plc

Mbouombouo (J.N.). (2007). Banque contre Microfinance: les enjeux de l'intermédiation financière dans la zone CEMAC, Edition CLE

Medamkam Toche (S.J) (2005/2006). La sécurité du Déposant dans le system bancaire de la CEMAC, Mémoire de DEA, Université de Dschang

Nah (T.F). (2009). Banking Law (Lectures Notes, Masters I), University of Dschang

Saunders and Linda A. (2010). Credit Risk Management In and Out of the Financial Crisis. $3^{\text {rd }}$

Saunders, M., P. Lewis, and Thornhill, A. (2009), Research Methods for Business Students. London: Pearson Edition Wiley \& Sons, Inc. 